\title{
Description of a new species of Xyletinus Latreille, 1809 from South Kazakhstan with a note on Xyletinus (Xeronthobius) desertus (Barovskij, 1929) (Coleoptera: Ptinidae: Xyletininae)
}

\section{Описание нового виАа Xyletinus Latreille, 1809 из Южного Казахстана с замечанием по Xyletinus (Xeronthobius) desertus (Barovskij, 1929) (Coleoptera: Ptinidae: Xyletininae)}

\author{
A.V. Kovalev', ${ }^{1,2}$ A.M. Shapovalovev ${ }^{2,3}$ \\ А.В. Ковамев ${ }^{1,2}$, А.М. Шаповамов ${ }^{2,3}$
}

\begin{abstract}
${ }^{1}$ All-Russian Institute of Plant Protection, Podbelsky Roadway, 3, St. Petersburg - Pushkin 196608 Russia. E-mail: melasis313@gmail.com ${ }^{2}$ Zoological Institute RAS, Universitetskaya nab., 1, St. Petersburg 199034 Russia

${ }^{3}$ Institute of Steppe of the Ural Branch of the Russian Academy of Sciences, Pionerskaya str., 11, Orenburg 460000 Russia. E-mail: Sitaris@ zin.ru
\end{abstract}

${ }^{1}$ Всероссийский научно-исследовательский институт защиты растений, шоссе Подбельского, 3, Санкт-Петербург - Пушкин 196608 Россия

²3оологический институт РАН, Университетская наб., 1, Санкт-Петербург 199034 Россия

${ }^{3}$ Институт степи Уральского отделения РАН, ум. Пионерская, 11, Оренбург 460000 Россия

Key words: Coleoptera, Ptinidae, Xyletinus, Xeronthobius, new species, taxonomy, Palaearctic. Ключевье слова: Coleoptera, Ptinidae, Xyletinus, Xeronthobius, новый виА, таксономия, Палеарктика.

Abstract. A new species Xyletinus (Xeronthobius) aralensis sp. n. from South Kazakhstan (Kyzylorda Region) is described. A new synonymy is established: X. $($ Xeronthobius $)$ desertus (Barovskij, 1929) $=$ X. $($ X.) kozlovi Emetz in Emetz et Logvinovskij, 1977, syn. n.

Резюме. Описан новый виА Xyletinus (Xeronthobius) aralensis sp. n. из Южного Казахстана (Кызылординская область). Установлена новая синонимия: X. (Xeronthobius) desertus (Barovskij, 1929) = X. (X.) kozlovi Emetz in Emetz et Logvinovskij, 1977, syn. n.

Among Coleoptera specimens recently collected a new species of the genus Xyletinus Latreille, 1809 was found. The new species should be assigned to the subgenus Xeronthobius F. Morawitz, 1863, characterized by the large and strongly protruding, circular eyes in the lateral view, and long tarsi, which are almost as long as their tibiae [Gottwald, 1977; Español, 1979; Toskina, 2010], and currently comprising 17 described species [Toskina, 2010] distributed in arid and semiarid regions of Palaearctic.

The type and other specimens examined are deposited in the collection of the Zoological Institute RAS (ZIN, St. Petersburg, Russia).

\section{Xyletinus (Xeronthobius) aralensis $\mathbf{s p .} \mathbf{n}$. (Color plate 3: 1-8)}

Material. Holotype, $\widehat{\jmath}$ (Color plate 3: 1): 46 $57^{\prime} 55.5^{\prime \prime} \mathrm{N} / 61^{\circ} 29^{\prime} 7.7^{\prime \prime} \mathrm{E}$ South Kazakhstan, Kyzylorda Region, Aral District, Kumsagyz railway station environment, 23.05.2014 (A.M. Shapovalov leg.). Paratype: $1 \hat{}$, same data as holotype.

Description. Body length $7.8 \mathrm{~mm}$, maximum width $2.95 \mathrm{~mm}$, body moderately convex.

Head blackish brown with brown anterior edge of the frons; pronotum and elytra brown; disc of pronotum, distal part of scutellum, sutural interval at base, basal edge and humeral region of elytra as well as epipleura somewhat lighter; underside mostly blackish brown. Antennae nearly unicolorous brownish yellow, antennomere 1 somewhat darker. Labrum brown; mandibles brown with blackish lateral and mesal edges; palpi testaceous. Legs light brown. Head and pronotum dull, elytra moderately shining. Upperside covered with very short and fine grayish-yellow appressed pubescence.

Head large; frons slightly convex, about 1.75 times as wide as eye diameter, slightly impressed between the antennal insertions and in front of them, with a weak trace of median keel. Eyes large, strongly protruding and circular in lateral view.

Antennae long, serrate, antennomere 3 subtriangular, 1.5 times as long as wide; antennomere 4 about 1.25 times as long as wide, with moderately produced subacute apical angle; antennomeres 5-10 longitudinal, some gradually becoming more slender and with less produced apical angles towards the apex: length and maximum width ratio of antennomere $5-1.28$; antennomere 10 - 4.17; antennomere $11-7.2$ times as long as wide and 1.3 times as long as antennomere 10 (Color plate 3: 2).

Maxillar palpomere 4 elongate, 4.4 times as long as wide, subparallel, its distal edge obliquely truncated (Color plate 3: 3). Labial palpomere 3 elongate, 3.25 times as long as wide, with convex external edge.

Pronotum comparatively small, transverse, 1.64 times as wide as long at midline and approximately 1.2 times as wide as head, widest before the middle (Color plate 3: 4). Anterior angles of the pronotum subrectangular, narrowly rounded; lateral margins of pronotum narrowly flattened until anterior angles, in dorsal view forming nearly even arc with pronotal base, in lateral view weakly $\mathrm{S}$-shaped, posterior angles of pronotum widely rounded and barely marked. Surface of pronotum more or less evenly convex. Pubescence on median part of pronotal disc directed obliquely from midline.

Scutellum somewhat longer than wide, subtrapezoidal, flattened at apex, slightly convex.

Elytra moderately convex, elongate, subparallel, slightly widened apically, 1.95 times as long as wide combined, about 4.5 times as long as and about 1.4 times as wide as pronotum. 
Elytra with finely impressed striae; discal striae strongly reduced before the elytral apices: only stria 10 distinctly reaching the elytral apices, other striae broken off and smoothed. Uneven intervals slightly narrower than the even ones. Interval 1 behind scutellum distinctly raised; intervals 3, 5, 7 and 9 somewhat more convex than others, and becoming more raised towards the elytra apices. Elytral pubescence directed obliquely from suture near the scutellum, at base of first elytral intervals, and directed obliquely from lateral margins on 9-11 elytral intervals at anterior half of elytra; another part of elytral surface with pubescence directed apically.

Median furrow of metaventrite wide and deep in posterior half, becoming narrower and shallow anteriorly and almost reaching anterior edge of metaventrite. Metacoxal plates short along entire width.

Apical edge of abdominal ventrite 1 evenly arcuate. Dista part of genital segment without median projection, median part of cross-piece arcuately concave (Color plate 3: 6). Phallobase moderately long; penis about 4 times as long as its maximum width, evenly narrowed to widely rounded apex; endophallus with paired small spines at base, with a pair of groups of small to medium-sized spines behind the middle, its distal part with a large sclerite of complex shape and with two large nail-shaped spines (Color plate 3: 7).

Legs long; meso- and metafemora strongly extending beyond elytral margins. Tarsi long, metatarsi about as long as metatibiae; ratios of relative lengths of metatarsomeres $1-5$ as $2.48: 1.38: 0.9$ $0.67: 1$ (Color plate 3: 5).

Head with very dense, rough, confluent irregular punctation, interspaces between punctures partly forming wrinkles. Pronotum with very dense and rough, partly confluent punctures, interspaces between them very narrow, partly forming wrinkles. Elytra coarsely transversely wrinkled with interspersed moderately dense large punctures

Female. Unknown.

Variation. Body length of the paratype $8.45 \mathrm{~mm}$, maximum width $3.55 \mathrm{~mm}$; pronotum more widely transverse, about 1.7 times as wide as long at midline; uneven elytral intervals somewhat more raised than those in the holotype; penis more narrowed apically than in the holotype, about 3.75 times as long as its maximum width, phallobase somewhat longer (Color plate 3: 8).

Differential diagnosis. The new species differs clearly from all known species of Xeronthobius in the following combination of characters: body large $(7.8-8.45 \mathrm{~mm})$, moderately convex, blackish brown with dark brown pronotum and elytra and covered with very short and fine, recumbent pubescence; frons rather wide (its width as 1.75 times as great as diameter of the eye); antennae with distinctly longitudinal antennomeres 4-10; prothoracic segment small, distinctly narrower than combined elytral bases; lateral margins of pronotum narrowly flattened until its anterior angles; pubescence on the median part of pronotal disc directed obliquely towards both sides from the midline; elytra slightly widened apically with somewhat raised and more narrow uneven intervals than even ones; elytral striae strongly reduced apically, only stria 10 clearly reaching the elytral apices; meso- and metafemora strongly extending beyond elytral outline; metatarsi about as long as metatibiae; apical edge of abdominal ventrite 1 evenly arcuate; surface of the head and pronotum dull due to very dense and rough, and partly confluent punctation.

Another species of Xeronthobius with the metafemora distinctly extending beyond elytral outline and with partly reduced striae in the apical part of elytra $(X .(X$.$) desertus$ (Barovskij, 1929) $(=X .(X$.$) kozlovi Emetz in Emetz$ et Logvinovskij, 1977, syn. n.), X. (X.) lecerfi Kocher, 1954, X. (X.) uralicus Toskina, 2010) differ clearly from $X$. $(X$.$) aralensis sp. \mathbf{n}$. in the more convex and lighter colored body, larger pronotum, elytra not widened apically and with intervals subequal in width and height, less reduced elytral striae at the elytral apices, and metatarsi shorter than metatibiae. In addition to these characters $X$. (X.) lecerfi from the Atlas Mountains and $X$. (X.) uralicus from "Ural" (type locality) might be easily distinguished from the new species also in the much smaller body (4.5-5 $\mathrm{mm}$ long in $X$. (X.) lecerfi and $3.85 \mathrm{~mm}$ long in $X$. $(X$.$) uralicus )$. Xyletinus $(X$.) lecerfi also differs from the new species in the more serrate antennae with less elongate antennomeres 4-10, straight apical edge of the abdominal ventrite 1 , and structure of aedeagus. $X$. (X.) uralicus (described after single female with missed antennae) also might be distinguished from $X$. $(X$.) aralensis in the much larger frons, somewhat shorter elytra (1.8 times as long as wide combined), and much finer sculpture of head and pronotum. Xyletinus $(X$.) desertus from North-West China (Alashan) differs from the new species also in the strongly serrate antennae with less elongate antennomeres 4-10, longer elytra (2.3-2.4 times as long as wide combined) with even intervals darker than uneven ones, more curved apical edge of abdominal ventrite 1 , very dense and thick pubescence of the integument, fine sculpture of the head and pronotum, and structure of aedeagus.

Ecology. Unknown, both of the type specimens have been collected at light in sandy desert with Krascheninnikovia spp.

Etymology. The specific epithet refers to the type locality near the Aral Sea, where the type specimens were collected.

Xyletinus (Xeronthobius) desertus (Barovskij, 1929) (Color plate 3: 9-10)

$=$ Xyletinus (Xeronthobius) kozlovi Emetz in Emetz et Logvinovskij, 1977, syn. n.

In the course of the study of the type material of Xyletinus (Xeronthobius) kozlovi a specimen with labels “C.3. А^ашань, пустыня, Козцов, 10-23.VIII.08” (NW Alashan, desert, Kozlov, 10-23.VIII.[19]08), "Xeronthobius desertus m. Typ., W. Barovsky det." (handwritten by V.V. Barovskij), with golden circle and red label "Paratypus, ๙, Xyletinus kozlovi, sp. n. det. Emetz 1975” was found. This specimen fully fits to the original description by Barovskij [1929], and, therefore, herein designated as a lectotype of Xeronthobius desertus Barovskij, 1929. Other specimens from the type series ( $12 \hat{\jmath}$ and 29 including the holotype of Xyletinus kozlovi) are herein designated as paralectotypes.

Thus, the description of $X$. (X.) kozlovi was based on specimens of the type series of Xeronthobius desertus Barovskij, 1929, and X. (X.) kozlovi Emetz in Emetz et Logvinovskij, 1977 must be regarded as a junior synonym of $X$. (Xeronthobius) desertus (Barovskij, 1929). A record of X. (X.) desertus (Barovskij, 1929) to Kazakhstan [Zahradník, 2007] is erroneous.

\section{Acknowledgements}

The authors are very grateful to Dr. A.G. Kirejtshuk (ZIN) for valuable comments on the manuscript, and also to Dr. B.A. Korotyaev(ZIN), to V.M. Emetz (Voronezh State 


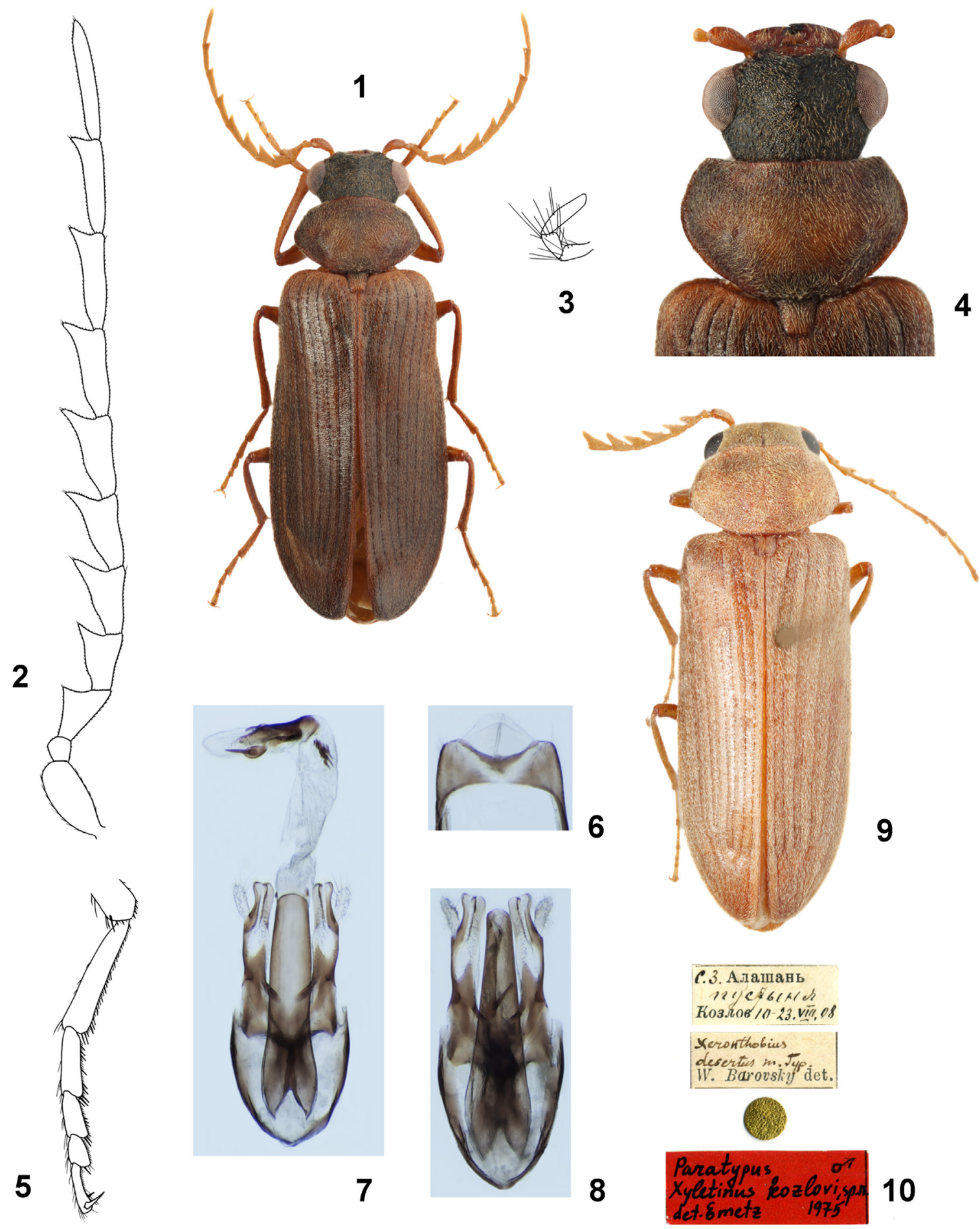

Figs 1-10. Xyletinus (Xeronthobius) spp.

1-8 - X. (X.) aralensis sp. n.: 1-5, 7 - holotype; 6,8 - paratype. 1 - general view; 2 - antenna; 3 - maxillary palpus; 4 - head with pronotum; 5 - metatarsus, lateral view; 6 - distal part of genital segment, dorsal view; 7 - aedeagus with everted endophallus, dorsal view; 8 - aedeagus, dorsal view; 9-10 - X. (X.) desertus (Barovskij, 1929), holotype: 9 - general view; 10 - labels.

Рис. 1-10. Xyletinus (Xeronthobius) spp.

1-8 - X. (X.) aralensis sp. n.: 1-5, 7 - голотип; 6, 8 - паратип. 1 - общий виА; 2 - антенна; 3 - нижнечелюстной щупик; 4 - голова и переднеспинка; 5 - метатарсус, виА сбоку; 6 - Аистальная часть генитального сегмента, виА сверху; 7 - эдеагус с вывернутым эндофалмусом, виА сверху; 8 - эдеагус, виА сверху; 9-10 - X. (X.) desertus (Barovskij, 1929), голотип: 9 - общий вид; 10 - этикетки. 
Biosphere Reserve, Russia) and to J.L. Torres (La Línea, Cádiz, Spain) for various assistance in studies of museum specimens and preparation of the paper.

This study was supported by the grants of Russian Foundation of Basic Research No 15-04-02971-a.

\section{References}

Barovskij V.V. 1929. Une espèce nouvelle asiatique du genre Xeronthobius Mor. (Coleoptera). Entomologicheskoe obozrenie. 23(3-4): 276.

Emetz V.M., Logvinovskij V.D. 1977. A review of anobiid-beetles of the genus Xyletinus Latr. (Coleoptera, Anobiidae) of the USSR. Entomologicheskoe Obozrenie. 56(2): 409-419 (in Russian).

Español F. 1979. Los Xyletinus Latr. de Marruecos (Col. Anobiidae, nota 89). Mediterránea. 3: 3-22.

Gottwald J. 1977. Die paläarktischen Xyletinus-Arten (Coleoptera, Anobiidae). Acta entomologica bohemoslovaca. 74.(3): 158-177.

Toskina I.N. 2010. Some new Palaearctic species and new key to species of the genus Xyletinus Latreille, 1809, subgenus Xeronthobius Morawitz, 1863 (Coleoptera: Anobiidae). Elytron. 22-23: 15-48.

Zahradník P. 2007. Ptinidae (without Gibbiinae and Ptininae). In: Catalogue of Palaearctic Coleoptera. Vol. 4. Elateroidea - Derodontoidea Bostrichoidea - Lymexyloidea - Cleroidea - Cucujoidea. (I. Löbl, A. Smetana eds). Stenstrup: Apollo Books: 339-362. 